\title{
Fiscal Rules and the Opportunistic Behaviour of the Incumbent Politician: Evidence from Italian Municipalities
}

\author{
DAVID BARTOLINI \\ RAFFAELLA SANTOLINI
}

CESIFO WORKING PAPER No. 2605

CATEgory 2: Public Choice

APRIL 2009

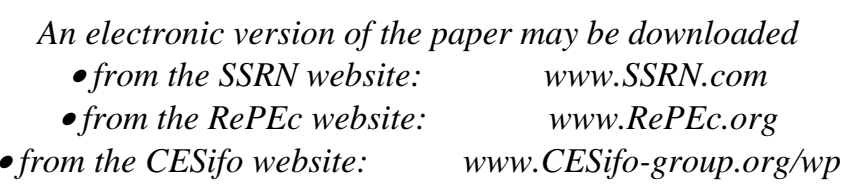




\title{
Fiscal Rules and the Opportunistic Behaviour of the Incumbent Politician: Evidence from Italian Municipalities
}

\begin{abstract}
Previous studies on electoral competition show that fiscal variables are manipulated by incumbent politicians in order to be re-elected. This phenomenon has been addressed by the literature on electoral budget cycle and, in a decentralised economy, by the literature on yardstick competition. Our objective is to consider the effect of the introduction of a fiscal rule on the opportunistic behaviour of incumbent politicians. We conduct a panel data analysis on the current expenditures of 246 Italian municipalities. The introduction of the domestic stability pact (DSP) seems to change the electoral cycle, by increasing the magnitude of the expenditures during pre-electoral periods. Moreover, our results show that municipalities affected by the DSP are more sensitive to changes in neighbouring jurisdictions' fiscal policies, during pre-electoral periods. We conclude that the introduction of the DSP, besides significantly reducing the level of local public spending, strengthens the opportunistic behaviour of incumbent politicians in pre-electoral years.
\end{abstract}

JEL Code: C23, C21, D72, H72.

Keywords: fiscal rules, electoral budget cycle, yardstick competition, system GMM, spatial econometrics.

\author{
David Bartolini \\ Department of Economics \\ Polytechnical University of Marche \\ Piazzale Martelli, 8 \\ Italy-60121 Ancona \\ d.bartolini@univpm.it
}

\author{
Raffaella Santolini \\ Department of Economics \\ Polytechnical University of Marche \\ Piazzale Martelli, 8 \\ Italy-60121 Ancona \\ r.santolini@univpm.it
}

March 28, 2009

We are grateful for their helpful comments to Christian Bruns, Barbara Ermini, Leonzio Rizzo, and participants at the CESifo 2nd Political EconomyWorkshop in Dresden, Germany. Usual disclaimer applies. 


\section{Introduction}

The theoretical literature provides a rational explanation for the opportunistic behaviour of incumbent politicians based on their desire to be re-elected. According to the electoral budget cycle (EBC) approach, the incumbent uses the budget in order to influence voters' opinion (Nordhaus, 1975; Rogoff, 1990; Besley and Case, 1995a). In a decentralised setting, the opportunistic behaviour is also related to yardstick competition, because citizens may compare the performance of their incumbent politicians with the performance of politicians in neighbouring jurisdictions (Salmon, 1987; Besley and Case, 1995b).

Many studies have found empirical evidence of electoral budget cycle and yardstick competition, both at the national and local level. ${ }^{1}$ However, only few works have considered the effects of the introduction of fiscal rules on the politicians' opportunistic behaviour. ${ }^{2}$ For instance, Mink and De Haan (2005) show that the Stability and Growth Pact, imposed on EU Member States, does not eliminate the electoral budget cycle, as governments tend to run deficits in the election year.

Our objective is to investigate the effects of a domestic fiscal rule on both electoral budget cycle and yardstick competition. Firstly, we ask whether there is evidence of such opportunistic behaviour in our local sample; then, we study the effect of the introduction of a domestic stability pact (DSP) on both phenomena. The DSP mainly consists in a limit to the budget deficit, which could reduce the incumbent ability to manipulate fiscal variables, and, as a consequence, it should make it more difficult to engage in the opportunistic behaviour.

We conduct an empirical investigation on a panel of Italian municipalities, from 1994 to 2003. Our analysis focuses on the spending side of the budget, as we consider the possibility that incumbent politicians modify spending in order to increase their chances to be re-elected. Although the fiscal rule targets the whole budget, we do not think restricting the analysis to the expenditure side poses any problem. Indeed, at the local level, politicians do not have much control over their fiscal revenues. This is particularly true for Italian municipalities, where mayors have almost no tax power. The revenue of municipalities mainly consists of transfers from the central government and few "local" taxes managed at the central level. Therefore, the opportunistic behaviour of the incumbent politician can only influence the expenditure side of the budget.

\footnotetext{
${ }^{1}$ Alesina et al. (1992) and Shi and Svensson (2002) provide evidence of political business cycle in OECD democratic countries. At the local level empirical evidence of the electoral cycle has been found by Bhattacharyya and Wassmer (1995), Mouritzen (1989), Galli and Rossi (2002), Petterson-Lidbom (2003), and Veiga and Veiga (2007). Evidence of yardstick competition is detected by Allers and Elhorst (2005), Bordignon et al. (2003) and Solé-Ollé (2003).

${ }^{2}$ These works mainly focus on the impact of fiscal rules on macroeconomic variables (Von Hagen, 1991; Poterba, 1995; Alesina and Bayoumi, 1996).
} 
Our empirical analysis provides clear evidence of the electoral budget cycle, as current expenditures significantly increase in the election year. The introduction of the DSP does not eliminate this opportunistic behaviour, even though it has a negative impact on the overall level of spending. This suggests that the DSP is quite effective in controlling the budget of local administrations. A closer look at the behaviour of politicians affected by the DSP, shows that only the opportunistic behaviour in the pre-electoral year is statistically significant. This can be a signal of either a shift of the electoral cycle to the pre-election year or a smoothing of the opportunistic behaviour over the pre-election and the election year.

As regards yardstick competition, the analysis shows that municipalities affected by the DSP are more sensitive to changes in fiscal policies of neighbouring jurisdictions during pre-electoral periods. It seems that the DSP reinforces the mimicking behaviour of politicians, as it could represent an additional element of comparison between neighbouring jurisdictions. For instance, if most neighbouring jurisdictions comply with the DSP, it could be a signal of bad performance not to comply with it.

To summarise, although the introduction of the DSP does not eliminate the opportunistic behaviour of incumbent politicians, it changes the way in which it is conducted, strengthening the increase of expenditures in the preelection year, and the responsiveness to changes in spending of neighbouring municipalities.

The rest of the paper is organised as follows: in the next section we give a brief description of Italian municipalities and fiscal rules; then, we describe the data and the methodology used to conduct our empirical investigation; in section 4 , we report estimation results; finally, in section 5, we conclude.

\section{Fiscal rules and Italian municipalities}

As a consequence of the Stability and Growth Pact, many European countries have introduced fiscal rules to limit the expenditures of local administrations. Fiscal rules usually consist in a limitation to the budget deficit and/or a direct limit to the spending growth rate. In most European countries local fiscal rules impose budget balance restrictions (e.g., Austria, Belgium, Germany, Italy, the Netherlands). In some of these countries (e.g., Germany and Belgium) fiscal rules encompass also a constraint on the expenditure growth rate. In Italy the law 448/1998 prescribes the implementation of a Domestic Stability Pact (DSP) which limits the budged deficit of local governments from the year 1999 onwards. The scope of the law spans over all levels of the Italian territorial administrative structure: regions, provinces and municipalities. However, from the year 2001 municipalities with a population smaller than 5000 inhabitants were excluded from the DSP. In the year 2002 and from the year 2005 onwards, there has been an extension of the scope of the DSP, imposing also a limit to the growth rate of expenditures. However, since our sample ends in 2003, the 
DSP considered in our work mainly consists in a budget deficit limitation. In most EU countries, a violation of such fiscal rules does not result in a direct penalty. For instance in Italy, the fiscal rule is seen as a mean to comply with the EU stability and growth pact, hence, only if the EU imposes some sanctions on the State, these are passed on to the local level of government according to DSP violations ${ }^{3}$ (Sutherland et al., 2005).

Recent studies on the Italian DSP highlight that only $66 \%$ of the municipalities fulfilled the DSP requirements in 1999, the year of the introduction of the DSP, and that only from the year 2003 the share of municipalities complying with the DSP rose to $92 \%$ (Patrizii et al., 2005). However, we show that the DSP has lead to a statistically significant reduction in the expenditure of the local administrations.

Fiscal rules usually refer to the budget balance, thus the analysis can be conducted on both expenditure and taxation sides. As mentioned in the introduction, we focus on the level of spending, for Italian municipalities have low tax autonomy. ${ }^{4}$ Furthermore, mayors have a substantial power to implement local policies and are directly accountable for the outcome. ${ }^{5}$ Therefore, the opportunistic behaviour is mainly focused on the expenditure side.

\section{Data and methodology}

The empirical analysis is conducted from 1994 to 2003 using a balanced panel data on 246 Italian municipalities located in the Marche region. We consider data on current public expenditures taken from local councils' balance sheets. The impact of the DSP on the current expenditures is tested by the introduction of a dummy that assumes value 1 when a municipality is subject to the DSP, and zero otherwise. A negative impact of this dummy on current spending is expected. In the year 2001, Italian municipalities with a population lower than 5000 people have been excluded from the DSP, they represents $27 \%$ of our sample.

The presence of electoral competition is investigated using data on election and pre-election years. ${ }^{6}$ Public expenditures at the local level are significantly affected by the socio-economic and the political characteristics of municipalities (Ermini and Santolini, 2007; Santolini, 2008). To take this into account, we include data on these socio-economic features in our data set. We consider population and population density, as a positive impact of both variables on

\footnotetext{
${ }^{3}$ In 2005 the rules of the DSP changed, introducing sanctions in case local governments do not respect the DSP.

${ }^{4}$ Recently, the government drastically reduced the scope of one of the few taxes (partially) managed by municipalities: the property tax, namely Imposta Comunale sugli Immobili (ICI).

${ }^{5}$ In the year 1992, a reform of the Italian electoral law introduced a majority regime, where citizens directly vote for their mayor, which led to a concentration of powers (and responsibilities) on mayors' hands.

${ }^{6}$ In the period considered there are, on average, three elections in each council.
} 
current expenditure (i.e., the dependent variable) is consistent with congestion effects while a negative sign denotes economies of scale. Additionally, we include the percentage of old people (greater or equal than 65 year old), to account for the possibility that expenditures are driven by social programs for elderly people. Data on the economic characteristics of the jurisdictions, such as per-capita income ${ }^{7}$ and per-capita grants from the central government, are also considered in the regression analysis. We expect a positive correlation of both variables with current expenditures. For instance, a positive value of the coefficient associated with income, would be consistent with the Wagner's law, which implies an increase of public expenditures as a consequence of economic development. We also control for partisan affiliation effects, introducing two dummies that assume value 1 when the municipality is ruled by the left(right)-wing coalition, and zero otherwise. This would account for the possibility that the expenditure is affected by political ideology. Accordingly, a positive (negative) impact on public expenditure is expected when the left(right)-wing coalition rules the jurisdiction. Finally, we consider the impact of large majorities on the opportunistic behaviour. We expect that politicians elected with a large share of votes have less incentive to increase expenses, as they face a lower political competition. Summary statistics of the above-mentioned variables are reported in table 1.

In the regression analysis we consider the logarithm of both dependent and control variables, to partially remove heteroschedasticity problems which affect data on current public expenditure of municipalities in the Marche region (Ermini and Santolini, 2007; Santolini, 2008).

\subsection{Dynamic models of electoral budget cycle}

A fairly standard model to test for the presence of the electoral budget cycle is represented by a dynamic specification of current expenditures. We extend this model by introducing a dummy to account for the effect of the domestic stability pact (see equation 1).

$$
\begin{aligned}
\exp _{i t}= & a+\beta \exp _{i t-1}+\delta_{1} \text { election }_{i t}+\delta_{2} \text { prelection }_{i t}+\phi D S P_{i t}+ \\
& +\gamma x_{i t}^{\prime}+\alpha_{i}+\mu_{i t}
\end{aligned}
$$

The dependent variable, $\exp _{i t}$, corresponds to a $N \times 1$ vector of cross-sectional time series observations on current expenditure in municipality $i$ (for $i=$ $1, \ldots, N$ ) at time period $\mathrm{t}$ (for $t=1, \ldots, T$ ). As regressors we consider the constant term $a$, the first order lagged dependent variable $\exp _{i t-1}$, the election year dummy election ${ }_{i t}$, which accounts for the opportunistic behaviour of the

\footnotetext{
${ }^{7}$ Since a panel data of disposable income is not available for Italian municipalities, we use statistics on the income tax base - Imposta sul Reddito delle Persone Fisiche (IRPEF).
} 
incumbent politician during the electoral period. This dummy is a $N \times 1$ vector that assumes value 1 when elections occur at time $t$, and zero otherwise. A positive sign of the coefficient $\delta_{1}$ is expected when the incumbent engages in electoral budget cycle. According to Rogoff (1990), we expect an increase in public expenditures in the periods before the election. Therefore, we add a preelection year dummy, prelection ${ }_{i t}$, that assumes value 1 when the municipality is in the pre-election year, and zero otherwise. In order to test the robustness of our model we follow Mink and De Haan (2005)'s approach, substituting the election and pre-election dummies with two electoral indexes. These indexes, developed by Franzese (2000), capture the exact period in which the election is held. The election indexes are calculated as,

$$
\begin{aligned}
\text { eleindex }_{i t} & =\frac{\left[(m-1)+\frac{d}{D}\right]}{12} \\
\text { preleindex }_{i t} & =1-\frac{\left[(m-1)+\frac{d}{D}\right]}{12}
\end{aligned}
$$

where $m$ and $d$ are the month and the day in which the election takes place, while $D$ is the number of days of $m$.

In all econometric models, we include a $1 \times K$ vector of control variables $x_{i t}^{\prime}=\left(x_{i t}^{1} \ldots, x_{i t}^{K}\right)$, consisting of: $i$ ) population density (i.e., population per $\left.\mathrm{km}^{2}\right)$; $\left.i i\right)$ population size; iii) percentage of young people (0-14 year old); iv) percentage of old people ( $\geq 65$ year old); $v$ ) per-capita income and pre-capita grants from the central government. A $N \times 1$ vector of municipality effects, $\alpha_{i}$, is also considered in model 1. Finally, we consider the error term $\mu_{i t}$, which is independent and identically distributed with zero mean and constant variance $\sigma_{\mu}^{2}$

The effect of the fiscal rule on the opportunistic behaviour of incumbent politicians is analysed with the interaction term between the DSP and (pre-) election year dummies, as shown in (2). We expect the introduction of the DSP would reduce it.

$$
\begin{aligned}
\exp _{i t}= & a+\beta \exp _{i t-1}+\delta_{1} \text { election }_{i t}+\delta_{2} \text { prelection }_{i t}+\phi D S P_{i t}+ \\
& +\theta_{1} \text { election }_{i t} D S P_{i t}+\gamma x_{i t}^{\prime}+\alpha_{i}+\mu_{i t}
\end{aligned}
$$

This dynamic panel data model cannot be estimated by the fixed-effect (FE) estimator when $T$ is fixed and $N$ goes to infinity, as the estimator would be biased and inconsistent (Verbeek, 2008). A possible solution is the first difference estimator developed by Anderson and Hsiao (1981, 1982). Although this estimator is easy to implement, it is less efficient than other estimators based on the generalised method of moments (GMM). In particular, we refer to the difference GMM (GMM-DIF) and the system GMM (GMM-SYS) estimators (Arellano and Bond, 1991; Arellano and Bover, 1995; Blundell and 
Bond, 1998). Both estimators require the first-order autocorrelation in the first differenced error term to be different than zero. However, their consistency depends on the presence of the second-order autocorrelation in the differenced residuals. Both conditions are detected by using specification tests developed by Arellano and Bond (1991). In the empirical analysis we refer to them as $A B$-AR1 test, in the case of first order autocorrelation analysis, and $A B-A R 2$ test for the second order autocorrelation analysis.

The dynamic model is estimated with the GMM-SYS estimator which is a combination of a set of standard equations in first-difference and equations in levels, distinctly instrumented. A one-step version of the GMM-SYS estimator, corrected for heteroscedasticity, is adopted because the efficiency gains of using the two-step version is quite small (Bond et al., 2001). The validity of the set of instruments is detected by the standard Hansen test of overidentifying restrictions (Arellano and Bover, 1995; Blundell and Bond, 1998), even though the proliferation of instruments can seriously weaken this test and overfit the endogenous variables (Bowsher, 2002; Roodman, 2007). Furthermore, the validity of the additional set of instruments used in GMM-SYS estimations is tested by using the Difference Hansen statistic (Blundell and Bond, 1998, 2000; Bond et al., 2001).

\subsection{Spatial econometric techniques and yardstick competition}

In order to consider the effects of the DSP on the opportunistic behaviour stemming from yardstick competition, we need to apply spatial econometric techniques (Anselin et al., 2008). Firstly, we estimate the intensity of the expenditure interaction among neighbouring jurisdictions considering a twoway fixed effect model, with a $N \times 1$ vector of time effects, $\tau_{t}$, as described in equation (3).

$$
\exp _{i t}=b+\rho \sum_{j=1}^{N} w_{i j} \exp _{j t}+\delta_{1} \text { election }_{i t}+\gamma x_{i t}^{\prime}+\alpha_{i}+\tau_{t}+\mu_{i t}
$$

The spatial dimension of the model is captured by the $N \times N$ spatial weight matrix, $W$, whose elements $w_{i j}$ for $\mathrm{i} \neq \mathrm{j}$ assume value 1 when municipality $j$ shares a border with municipality $i$, and zero otherwise. When $i=j$, we assume that $w_{i j}=0$ (Anselin, 1988). Usually, the rows of $W$ are standardised to 1 , so that $\sum_{j=1}^{N} w_{i j}=1$. When we multiply the elements $w_{i j}$ of the spatial weight matrix by those of the current spending in other municipalities, i.e. $\sum_{j=1}^{N} w_{i j} e p_{j t}$, we obtain the average public expenditures of contiguous municipalities, so that the coefficient $\rho$ measures the intensity of the spending interaction.

The meaning attached to the coefficient $\rho$, however, is consistent with several theories. For instance, $\rho$ could also be thought of as a measure of spill-over 
effects, or fiscal competition. Therefore, in order to detect yardstick competition, we estimate the expenditure interaction among neighbouring municipalities in election and non-election years. According to the yardstick competition approach (Solé-Ollé, 2003), incumbent politicians in election year show a stronger intensity of fiscal interaction than incumbents not in election year, as they increase their chances of being re-elected by copy-catting neighbouring fiscal policies. Therefore, we modify model (3) introducing two spatial lagged regimes $\rho_{1}$ and $\rho_{2}$ as in Allers and Elhorst (2005). The coefficients $\rho_{1}$ and $\rho_{2}$ measure the intensity of the expenditure interaction among municipalities in election and non-election year, respectively. A positive sign of $\rho_{1}$ stands for strategic complementarity, which can be a signal of yardstick competition only if $\rho_{1}$ is significantly greater than $\rho_{2}$. Since we consider two spatial regimes, the constant term $b$ is replaced by two complementary intercepts: election $n_{i t}$ and $\left(1-\right.$ election $\left._{i t}\right)$. This is summarised in equation (4).

$$
\begin{aligned}
\exp _{i t}= & \rho_{1} \sum_{j=1}^{N} w_{i j} \exp _{j t} \text { election }_{i t}+\rho_{2} \sum_{j=1}^{N} w_{i j} \exp _{j t}\left(1-\text { election }_{i t}\right)+ \\
& +\varphi_{1} \text { election }_{i t}+\varphi_{2}\left(1-\text { election }_{i t}\right)+\gamma x_{i t}^{\prime}+\alpha_{i}+\tau_{t}+\mu_{i t}
\end{aligned}
$$

We also test for the presence of yardstick competition in the pre-electoral period replacing election et $_{\text {with }}$ prelection $_{i t}$ dummies in (4). We have the same expectations for the sign and magnitude of $\rho_{1}$ and $\rho_{2}$, as in the previous model.

The impact of the DSP on yardstick competition is analysed in equation (5). In detail, we consider the average of current expenditures of municipalities that, at the same time, are in election year and subject to the DSP, that is the first regressor in equation (5). The presence of yardstick competition is denoted by $\rho_{1}^{d}>0$ and $\rho_{1}^{d}>\rho_{2}$. We reach a similar conclusion for municipalities in pre-election and non pre-election year by replacing election ${ }_{i t}$ with prelection $_{i t}$. On the other hand, the intensity of the expenditure interaction among municipalities in (pre-)election year but not subjected to the DSP is measured by parameter $\rho_{1}^{\text {nd }}$.

$$
\begin{aligned}
\exp _{i t}= & \rho_{1}^{d} \sum_{j=1}^{N} w_{i j} \exp _{j t} \text { ele }_{i t} D S P_{i t}+\rho_{1}^{n d} \sum_{j=1}^{N} w_{i j} \exp _{j t} \text { ele } e_{i t}\left(1-D S P_{i t}\right)+ \\
& +\rho_{2} \sum_{j=1}^{N} w_{i j} \exp _{j t}\left(1-\text { ele }_{i t}\right)+\varphi_{1}^{d} \text { ele }_{i t} D S P_{i t}+ \\
& +\varphi_{1}^{n d} \text { ele }_{i t}\left(1-D S P_{i t}\right)+\varphi_{2}\left(1-e l e_{i t}\right)+\gamma x_{i t}^{\prime}+\alpha_{i}+\tau_{t}+\mu_{i t}
\end{aligned}
$$

All spatial empirical models are estimated adopting a feasible efficient twostep GMM estimator with robust standard errors (Anselin, 1988; Baum et al., 
2003). Since it is a two-stage estimator, is consistent when data suffer from heteroscedasticity and non-normally distributed error terms (Anselin, 1988). Additionally, it is consistent with the presence of spatial auto-correlated shocks (Kelejian and Prucha, 1998), thereby the correlation in the level of $\exp _{i t}$ does not depend on common shocks spatially distributed among jurisdictions (SoléOllé, 2006).

The average current expenditure of municipalities needs to be instrumented (Anselin, 1988). In particular, model (3) is instrumented with $x_{i t}^{\prime}$ and $\sum_{j}^{N} w_{i j} x_{i t}$ as suggested by Kelejian and Prucha (1998). Similarly, instrumental variables for (4) are $x_{i t}^{\prime}, \sum_{j}^{N} w_{i j} x_{i t}$ election $_{i t}$, and $\sum_{j}^{N} w_{i j} x_{i t}\left(1-\right.$ election $\left._{i t}\right)$. In (5), it is possible to use $\sum_{j}^{N} w_{i j} x_{i t}$ election $_{i t} D S P_{i t}, \sum_{j}^{N} w_{i j} x_{i t}$ election ${ }_{i t}\left(1-D S P_{i t}\right)$, and $\sum_{j}^{N} w_{i j} x_{i t}\left(1-\right.$ election $\left._{i t}\right)$ as the set of instruments. Similar instrumental variables are implemented when the pre-electoral period is considered. Additional instruments, such as electoral indexes and their average are also taken into account.

\section{Estimation results}

This section presents the results of the estimation of our econometric models. The results of the dynamic model (1), which accounts for the effect of the DSP on the electoral budget cycle, show that the DSP significantly reduces the expenditure of municipalities, the effect ranges between $(-0.07)$ and $(-0.03)$, while the positive and significant coefficient associated with the election year dummy accounts for the presence of an electoral budget cycle. Therefore, although the introduction of the DSP reduces public expenditures, it does not eliminate the electoral budget cycle.

In order to investigate the effect of the DSP on the behaviour of politicians facing elections, we consider the interaction terms between DSP and (pre) election year dummies. As reported in table 2, the interaction between the DSP and the prelection dummy is positive and significant, while the interaction with the election year is not statistically significant. This suggests that the introduction of the DSP strengthen the incumbent politicians' opportunistic behaviour in the pre-election period.

These results are robust to a different specification of the electoral and preelectoral dummies. We estimate models (1) and (2), substituting the electoral dummies with two indexes: eleindex and preleindex (Mink and De Haan, 2005). The estimation results are analogous to those presented in table (2), with respect to the sign and significance level of the coefficients. As regards control variables, we observe that the coefficient of per-capita income and grants are significant, and in line with our expectations. Contrary to the predictions of the political competition literature, we observe a positive and significant coefficient associated with the majority variable.

We conclude that the introduction of the DSP decreases the size of current 
public expenditure and modify the electoral cycle by inducing an increase of current spending in the pre-electoral period.

The second part of the analysis considers the presence of yardstick competition. Estimation results are reported in tables 4 and 5. Expenditure interaction is significant and occurs with a magnitude of 0.58. In order to discriminate yardstick competition from other possible causes of interaction, we interact the neighbouring expenditure with the electoral dummies, according to Solé-Ollé (2003). As shown in table 4, municipalities in (pre-) election year are more sensitive to neighbouring expenditure levels than municipalities facing no imminent elections. This evidence is not fully robust, as the p-value of the difference between the $\rho$ coefficients in the (pre-) election year, does not allow us to reject the null hypothesis of identical values.

The effect of the DSP on yardstick competition is shown in table 5, where we distinguish the effect of the DSP in the electoral and pre-electoral years. Results show that, in the election year, municipalities affected by the DSP react less (0.63) than municipalities not affected (0.71), and municipalities not in election year (0.68). Whereas, in the pre-election year, municipalities affected by the DSP are more sensitive than the other municipalities $(0.73$ against 0.68 and 0.63 for municipalities in pre-election year not affected by the DSP and municipalities not in pre-election year, respectively). This result suggests that politicians affected by the DSP, in pre-election year, are more sensitive to changes in fiscal policies of contiguous municipalities. This is a robust result, as the $\rho$-test for the interaction coefficients in the pre-election year, rejects the null hypothesis of identical values.

Summarising, the empirical analysis conducted so far suggests two interesting remarks. Firstly, although the DSP does not eliminate the electoral cycle, it changes the way in which it is conducted, because the expenditures increase is strengthen in the pre-election year. This is consistent with both a shift of the opportunistic behaviour to the pre-election year, or an extension of the opportunistic behaviour covering both election and pre-election years. The latter explanation is perhaps more consistent with the Italian context, as the DSP introduces a link between past and present budget which forces incumbent politicians to smooth the opportunistic behaviour over a wider time span.

Secondly, as regards political yardstick competition, we find that municipalities affected by the DSP are more sensitive to changes in fiscal policies of neighbouring jurisdictions during pre-electoral periods. It seems that the DSP reinforces the mimicking behaviour of politicians, as it could represent an additional element of comparison between contiguous jurisdictions. For instance, if neighbouring jurisdictions comply with the DSP, it would be a bad signal for the incumbent politician not to do so. 


\section{Conclusions}

The empirical analysis conducted on the behaviour of incumbent politicians in the Marche region, leads to three main results. Firstly, the DSP significantly reduces the expenditure of municipalities. Secondly, our analysis shows that the DSP does not eliminate the electoral budget cycle, rather it induces a change in the opportunistic behaviour of incumbent politicians. Thirdly, as regards yardstick competition, we show that incumbent politicians react to the introduction of the DSP by strengthening their response to changes in contiguous municipalities expenditures, in the pre-election period. 


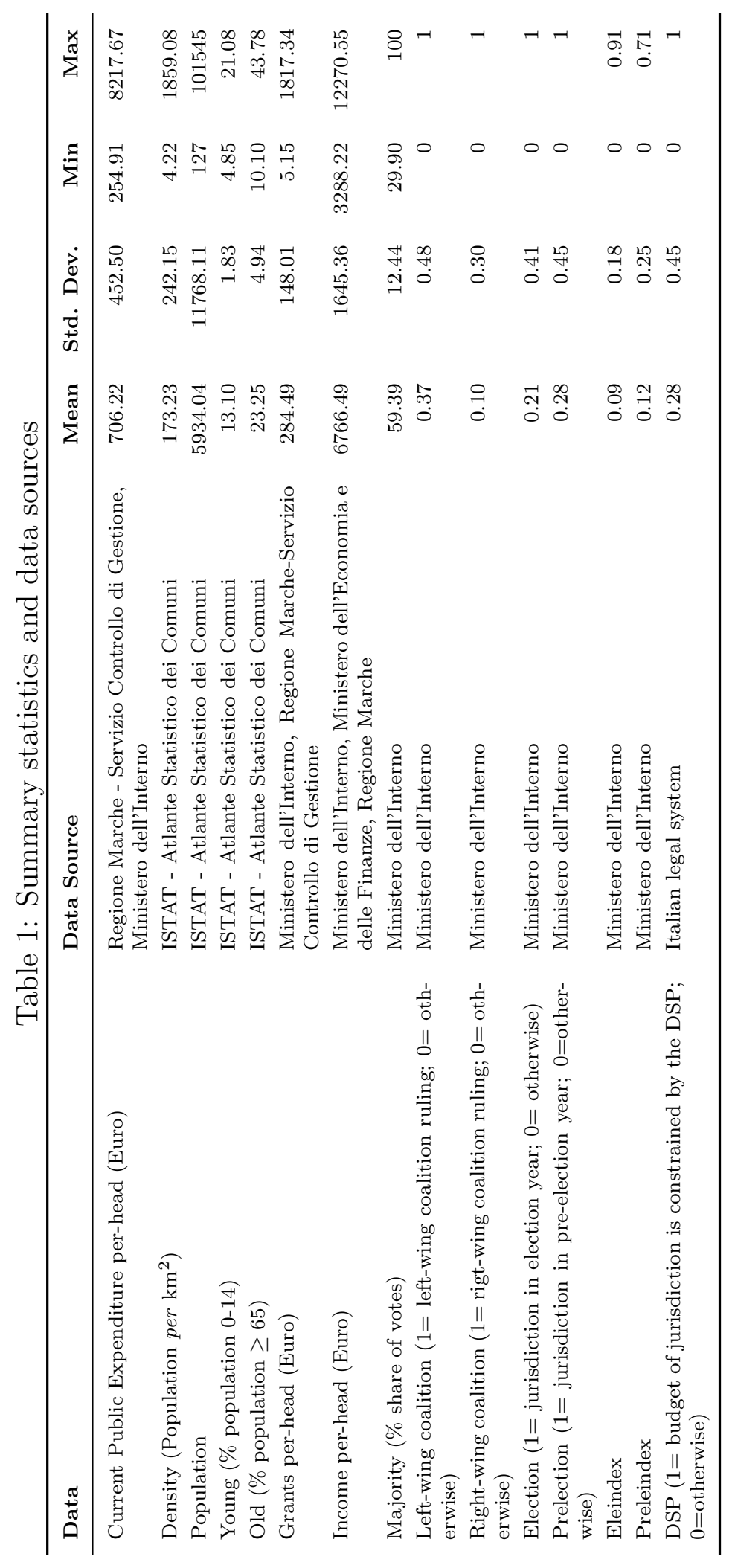


Table 2: Estimation results of the electoral budget cycle and DSP effects

\begin{tabular}{|c|c|c|c|c|c|c|}
\hline & \multicolumn{6}{|c|}{ Model } \\
\hline & (1) & (1) & $(2)$ & $(2)$ & $(2)$ & $(2)$ \\
\hline Election & $\begin{array}{l}0.05^{* * *} \\
(3.52)\end{array}$ & $\begin{array}{l}0.02 \\
(0.87)\end{array}$ & $\begin{array}{l}0.15^{*} \\
(1.83)\end{array}$ & $\begin{array}{l}0.09 \\
(1.02)\end{array}$ & $\begin{array}{l}0.06^{* * *} \\
(3.85)\end{array}$ & $\begin{array}{l}0.01 \\
(0.07)\end{array}$ \\
\hline Prelection & $\begin{array}{l}-0.001 \\
(-0.07)\end{array}$ & $\begin{array}{l}0.005 \\
(0.49)\end{array}$ & $\begin{array}{l}0.005 \\
(0.43)\end{array}$ & $\begin{array}{l}-0.006 \\
(-0.47)\end{array}$ & $\begin{array}{c}-0.009 \\
(-0.76)\end{array}$ & $\begin{array}{c}-0.004 \\
(-0.26)\end{array}$ \\
\hline DSP & $\begin{array}{l}-0.04 * * * \\
(-5.31)\end{array}$ & $\begin{array}{l}-0.06^{* * *} \\
(-4.44)\end{array}$ & $\begin{array}{l}-0.03^{* * *} \\
(-3.30)\end{array}$ & $\begin{array}{l}-0.06^{* * *} \\
(-3.65)\end{array}$ & $\begin{array}{l}-0.06^{* * *} \\
(-4.60)\end{array}$ & $\begin{array}{l}-0.07^{* * *} \\
(3.80)\end{array}$ \\
\hline DSP*Election & & & $\begin{array}{l}-0.10 \\
(-1.30)\end{array}$ & & $\begin{array}{l}-0.03 \\
(-0.31)\end{array}$ & $\begin{array}{l}0.02 \\
(0.20)\end{array}$ \\
\hline DSP*Prelection year & & & & $\begin{array}{l}0.17^{*} \\
(1.80)\end{array}$ & $\begin{array}{l}0.19^{* *} \\
(2.04)\end{array}$ & $\begin{array}{l}0.12 \\
(1.15)\end{array}$ \\
\hline Expenditure (t-1) & $\begin{array}{l}0.73^{* * *} \\
(4.19)\end{array}$ & $\begin{array}{l}0.64^{* *} \\
(2.97)\end{array}$ & $\begin{array}{l}0.75^{* * *} \\
(3.88)\end{array}$ & $\begin{array}{l}0.76^{* * *} \\
(4.03)\end{array}$ & $\begin{array}{l}0.75^{* * *} \\
(4.10)\end{array}$ & $\begin{array}{l}0.65^{* *} \\
(3.06)\end{array}$ \\
\hline Density & $\begin{array}{l}-0.01 \\
(-0.17)\end{array}$ & $\begin{array}{l}-0.17 \\
(-1.00)\end{array}$ & $\begin{array}{l}0.01 \\
(0.14)\end{array}$ & $\begin{array}{l}0.02 \\
(0.27)\end{array}$ & $\begin{array}{l}0.02 \\
(0.21)\end{array}$ & $\begin{array}{l}-0.12 \\
(-0.66)\end{array}$ \\
\hline Population & $\begin{array}{l}-0.003 \\
(-0.06)\end{array}$ & $\begin{array}{l}0.15 \\
(1.33)\end{array}$ & $\begin{array}{l}-0.02 \\
(-0.48)\end{array}$ & $\begin{array}{l}-0.02 \\
(-0.51)\end{array}$ & $\begin{array}{l}-0.02 \\
(-0.43)\end{array}$ & $\begin{array}{l}0.10 \\
(0.79)\end{array}$ \\
\hline Young & $\begin{array}{l}-0.69 \\
(-0.93)\end{array}$ & $\begin{array}{l}-0.42 \\
(-0.64)\end{array}$ & $\begin{array}{l}-0.81 \\
(-1.04)\end{array}$ & $\begin{array}{l}-0.74 \\
(-0.99)\end{array}$ & $\begin{array}{l}-0.71 \\
(-0.96)\end{array}$ & $\begin{array}{l}-0.54 \\
(-0.73)\end{array}$ \\
\hline Old & $\begin{array}{l}-0.16 \\
(0.63)\end{array}$ & $\begin{array}{l}-0.04 \\
(-0.09)\end{array}$ & $\begin{array}{l}-0.20 \\
(-0.72)\end{array}$ & $\begin{array}{l}-0.23 \\
(-0.96)\end{array}$ & $\begin{array}{l}-0.23 \\
(-0.96)\end{array}$ & $\begin{array}{l}-0.08 \\
(-0.22)\end{array}$ \\
\hline Income per-head & $\begin{array}{l}0.13^{*} \\
(1.77)\end{array}$ & $\begin{array}{l}-0.012 \\
(-0.12)\end{array}$ & $\begin{array}{l}0.14^{*} \\
(1.74)\end{array}$ & $\begin{array}{l}0.14^{*} \\
(1.80)\end{array}$ & $\begin{array}{l}0.14^{*} \\
(1.83)\end{array}$ & $\begin{array}{l}0.03 \\
(0.29)\end{array}$ \\
\hline Grants per-head & $\begin{array}{l}0.04^{*} \\
(1.65)\end{array}$ & $\begin{array}{l}0.02 \\
(0.65)\end{array}$ & $\begin{array}{l}0.04^{*} \\
(1.67)\end{array}$ & $\begin{array}{l}0.08^{* *} \\
(2.49)\end{array}$ & $\begin{array}{l}0.09 * * \\
(2.55)\end{array}$ & $\begin{array}{l}0.05 \\
(1.16)\end{array}$ \\
\hline Majority & & $\begin{array}{l}0.57^{*} \\
(1.71)\end{array}$ & & & & $\begin{array}{l}0.45 \\
(1.36)\end{array}$ \\
\hline Left-wing coalition & & $\begin{array}{l}-0.13 \\
(-1.00)\end{array}$ & & & & $\begin{array}{l}-0.09 \\
(-0.73)\end{array}$ \\
\hline Right-wing coalition & & $\begin{array}{l}0.02 \\
(0.05)\end{array}$ & & & & $\begin{array}{l}0.13 \\
(0.24)\end{array}$ \\
\hline Constant & $\begin{array}{l}2.79 \\
(1.05)\end{array}$ & $\begin{array}{l}0.88 \\
(0.31)\end{array}$ & $\begin{array}{l}2.95 \\
(1.03)\end{array}$ & $\begin{array}{l}2.53 \\
(0.90)\end{array}$ & $\begin{array}{l}2.47 \\
(0.89)\end{array}$ & $\begin{array}{l}1.31 \\
(0.44)\end{array}$ \\
\hline $\mathrm{AB}-\mathrm{AR} 1$ test & 0.000 & 0.003 & 0.000 & 0.000 & 0.000 & 0.002 \\
\hline AB-AR2 test & 0.121 & 0.288 & 0.763 & 0.847 & 0.593 & 0.517 \\
\hline Hansen $\mathrm{J}$ test & 0.138 & 0.235 & 0.230 & 0.479 & 0.538 & 0.369 \\
\hline Hansen-difference test & 0.342 & 0.686 & 0.092 & 0.402 & 0.812 & 0.453 \\
\hline
\end{tabular}

Note: $i$ ) instruments for first differences equation are $\exp _{i(t-4)}, \Delta$ population; $\left.i i\right)$ instruments for levels equation are the constant term, the second order difference of $\exp _{i(t-1)}$, and population; iii) the results of the tests are in p-value; $i v$ ) coefficient significant at level ${ }^{* * *} 1 \%$, ${ }^{* *} 5 \%,{ }^{*} 10 \%$; $v$ ) z-value in parenthesis; vi) observations: 2214 
Table 3: Estimation results using the electoral indexes

\begin{tabular}{|c|c|c|c|c|}
\hline & \multicolumn{4}{|c|}{ Model } \\
\hline & $(1)$ & (1) & $(2)$ & $(2)$ \\
\hline Eleindex & $\begin{array}{l}0.09 * * * \\
(3.38)\end{array}$ & $\begin{array}{l}0.04 \\
(0.82)\end{array}$ & $\begin{array}{l}0.27 \\
(0.80)\end{array}$ & $\begin{array}{l}-0.05 \\
(-0.10)\end{array}$ \\
\hline Preleindex & $\begin{array}{l}-0.005 \\
(-0.32)\end{array}$ & $\begin{array}{l}0.008 \\
(0.43)\end{array}$ & $\begin{array}{l}-0.02 \\
(-0.73)\end{array}$ & $\begin{array}{l}-0.005 \\
(-0.22)\end{array}$ \\
\hline DSP & $\begin{array}{l}-0.04^{* * *} \\
(-5.37)\end{array}$ & $\begin{array}{l}-0.06 * * * \\
(-4.52)\end{array}$ & $\begin{array}{l}-0.06^{* * *} \\
(-3.29)\end{array}$ & $\begin{array}{l}-0.07 * * * \\
(-3.53)\end{array}$ \\
\hline DSP*Eleindex & & & $\begin{array}{l}-0.12 \\
(-0.38)\end{array}$ & $\begin{array}{l}0.11 \\
(0.26)\end{array}$ \\
\hline DSP*Preleindex & & & $\begin{array}{l}0.32^{*} \\
(1.91)\end{array}$ & $\begin{array}{l}0.18 \\
(1.00)\end{array}$ \\
\hline Expenditure (t-1) & $\begin{array}{l}0.73^{* * *} \\
(4.28)\end{array}$ & $\begin{array}{l}0.64^{* *} \\
(2.93)\end{array}$ & $\begin{array}{l}0.74^{* * * *} \\
(3.83)\end{array}$ & $\begin{array}{l}0.64^{* *} \\
(2.90)\end{array}$ \\
\hline Density & $\begin{array}{l}-0.01 \\
(-0.12)\end{array}$ & $\begin{array}{l}-0.18 \\
(-1.04)\end{array}$ & $\begin{array}{l}0.02 \\
(0.22)\end{array}$ & $\begin{array}{l}-0.14 \\
(-0.77)\end{array}$ \\
\hline Population & $\begin{array}{l}-0.005 \\
(-0.11)\end{array}$ & $\begin{array}{l}0.15 \\
(1.39)\end{array}$ & $\begin{array}{l}-0.02 \\
(-0.51)\end{array}$ & $\begin{array}{l}0.12 \\
(0.93)\end{array}$ \\
\hline Young & $\begin{array}{l}-0.64 \\
(-0.89)\end{array}$ & $\begin{array}{l}-0.40 \\
(-0.62)\end{array}$ & $\begin{array}{l}-0.74 \\
(-0.92)\end{array}$ & $\begin{array}{l}-0.48 \\
(-0.61)\end{array}$ \\
\hline Old & $\begin{array}{l}-0.14 \\
(-0.55)\end{array}$ & $\begin{array}{l}-0.03 \\
(-0.07)\end{array}$ & $\begin{array}{l}-0.21 \\
(-0.82)\end{array}$ & $\begin{array}{l}-0.06 \\
(-0.14)\end{array}$ \\
\hline Income per-head & $\begin{array}{l}0.12^{*} \\
(1.74)\end{array}$ & $\begin{array}{l}-0.016 \\
(-0.15)\end{array}$ & $\begin{array}{l}0.16^{*} \\
(1.70)\end{array}$ & $\begin{array}{l}0.01 \\
(0.12)\end{array}$ \\
\hline Grants per-head & $\begin{array}{l}0.04 \\
(1.61)\end{array}$ & $\begin{array}{l}0.02 \\
(0.60)\end{array}$ & $\begin{array}{l}0.08^{* *} \\
(2.31)\end{array}$ & $\begin{array}{l}0.05 \\
(1.03)\end{array}$ \\
\hline Majority & & $\begin{array}{l}0.58^{*} \\
(1.77)\end{array}$ & & $\begin{array}{l}0.51 \\
(1.50)\end{array}$ \\
\hline Left-wing coalition & & $\begin{array}{l}-0.13 \\
(-1.01)\end{array}$ & & $\begin{array}{l}-0.10 \\
(-0.81)\end{array}$ \\
\hline Right-wing coalition & & $\begin{array}{l}0.01 \\
(0.03)\end{array}$ & & $\begin{array}{l}0.11 \\
(0.19)\end{array}$ \\
\hline Constant & $\begin{array}{l}2.60 \\
(1.00)\end{array}$ & $\begin{array}{l}0.79 \\
(0.28)\end{array}$ & $\begin{array}{l}2.50 \\
(0.86)\end{array}$ & $\begin{array}{l}1.05 \\
(0.34)\end{array}$ \\
\hline AB-AR 1 test & 0.000 & 0.003 & 0.000 & 0.002 \\
\hline AB-AR2 test & 0.080 & 0.283 & 0.917 & 0.478 \\
\hline Hansen $\mathrm{J}$ test & 0.095 & 0.226 & 0.459 & 0.300 \\
\hline Hansen-difference test & 0.304 & 0.697 & 0.430 & 0.472 \\
\hline
\end{tabular}

Note: i) instruments for first differences equation are $\exp _{i(t-4)}$, $\Delta$ population; ii) instruments for levels equation are the constant term, the second order difference of $\exp _{i(t-1)}$, and population; iii) the results of the tests are in p-value; $i v$ ) coefficient significant at level $* * * 1 \%, * * 5 \%$, $* 10 \% ; v)$ z-value in parenthesis; vi) observations: 2214. 
Table 4: Estimation results on yardstick competition

\begin{tabular}{|c|c|c|c|}
\hline & \multicolumn{3}{|c|}{ Model } \\
\hline & (3) & $(4)$ & $(4)$ \\
\hline Neigh Exp & $\begin{array}{l}0.58^{* * * *} \\
(5.32)\end{array}$ & & \\
\hline Neigh Exp*Election & & $\begin{array}{l}0.54^{* * *} \\
(5.82)\end{array}$ & \\
\hline Neigh Exp*No Election & & $\begin{array}{l}0.52^{* * *} \\
(5.51)\end{array}$ & \\
\hline Neigh Exp*Prelection & & & $\begin{array}{l}0.63^{* * *} \\
(6.54)\end{array}$ \\
\hline Neigh Exp*No Prelection & & & $\begin{array}{l}0.60^{* * *} \\
(6.12)\end{array}$ \\
\hline Election & $\begin{array}{l}-0.004 \\
(-0.64)\end{array}$ & $\begin{array}{l}1.27 \\
(1.43)\end{array}$ & $\begin{array}{c}-0.004 \\
(-0.61)\end{array}$ \\
\hline No Election & & $\begin{array}{l}1.38 \\
(1.53)\end{array}$ & \\
\hline Prelection & $\begin{array}{l}-0.004 \\
(-0.72)\end{array}$ & $\begin{array}{c}-0.004 \\
(-0.78)\end{array}$ & $\begin{array}{l}0.54 \\
(0.57)\end{array}$ \\
\hline No Prelection & & & $\begin{array}{l}0.77 \\
(0.81)\end{array}$ \\
\hline Density & $\begin{array}{l}-1.64^{* * *} \\
(-6.62)\end{array}$ & $\begin{array}{c}-1.44^{* * *} \\
(-11.45)\end{array}$ & $\begin{array}{c}-1.38^{* * *} \\
(-10.88)\end{array}$ \\
\hline Population & $\begin{array}{l}1.11^{* * *} \\
(7.27)\end{array}$ & $\begin{array}{l}0.88^{* * *} \\
(13.84)\end{array}$ & $\begin{array}{l}0.87^{* * *} \\
(13.72)\end{array}$ \\
\hline Young & $\begin{array}{l}0.09^{* *} \\
(3.02)\end{array}$ & $\begin{array}{l}0.09 * * \\
(2.98)\end{array}$ & $\begin{array}{l}0.09^{* *} \\
(3.14)\end{array}$ \\
\hline Old & $\begin{array}{l}0.07 \\
(1.30)\end{array}$ & $\begin{array}{l}0.058 \\
(1.07)\end{array}$ & $\begin{array}{l}0.06 \\
(1.23)\end{array}$ \\
\hline Income per-head & $\begin{array}{l}-0.01 \\
(-0.24)\end{array}$ & $\begin{array}{l}-0.01 \\
(-0.29)\end{array}$ & $\begin{array}{l}-0.017 \\
(-0.48)\end{array}$ \\
\hline Grants per-head & $\begin{array}{l}0.05^{* * *} \\
(3.75)\end{array}$ & $\begin{array}{l}0.05^{* * *} \\
(3.74)\end{array}$ & $\begin{array}{l}0.05^{* * *} \\
(3.79)\end{array}$ \\
\hline Majority & $\begin{array}{l}0.001 \\
(0.04)\end{array}$ & $\begin{array}{l}0.001 \\
(0.06)\end{array}$ & $\begin{array}{l}-0.0002 \\
(-0.01)\end{array}$ \\
\hline Left-wing coal. & $\begin{array}{l}0.02^{* * *} \\
(3.54)\end{array}$ & $\begin{array}{l}0.02^{* * *} \\
(4.05)\end{array}$ & $\begin{array}{l}0.02^{* * *} \\
(3.86)\end{array}$ \\
\hline Right-wing coal. & $\begin{array}{l}0.017^{* *} \\
(2.35)\end{array}$ & $\begin{array}{l}0.01^{* *} \\
(2.26)\end{array}$ & $\begin{array}{l}0.016^{* *} \\
(2.30)\end{array}$ \\
\hline Constant & $\begin{array}{l}-0.08 \\
(0.903)\end{array}$ & & \\
\hline Centred $\mathrm{R}^{2}$ & 0.94 & 0.97 & 0.97 \\
\hline Hansen $\mathrm{J}$ test & 0.407 & 0.362 & 0.158 \\
\hline$\rho$ test $=0$ & & 0.488 & 0.179 \\
\hline$\varphi$ test $=0$ & & 0.466 & 0.173 \\
\hline
\end{tabular}

Note: $i$ ) instrument variables in model 3 are the regressors and their average; ii) instrument variables in model 4 are the regressors, the regressors average interacted with the electoral (pre-electoral) dummies, the election index, the pre-election index, and the average of the election index; iii) results of the tests are in p-value; iv) coefficient significant at level $* * * 1 \%,{ }^{* *} 5 \%,{ }^{*} 10 \% ; v$ ) z-value in parenthesis; vi) observations: 2460. 
Table 5: Effects of the DSP on yardstick competition

\begin{tabular}{|c|c|c|}
\hline \multirow{3}{*}{ Neigh Exp*Election *DSP } & \multicolumn{2}{|c|}{ Model } \\
\hline & $(5)$ & $(5)$ \\
\hline & $\begin{array}{l}0.63^{* * *} \\
(7.18)\end{array}$ & \\
\hline Neigh Exp*Election * No DSP & $\begin{array}{l}0.71^{* * *} \\
(8.53)\end{array}$ & \\
\hline Neigh Exp*No Election & $\begin{array}{l}0.68^{* * *} \\
(8.11)\end{array}$ & \\
\hline Neigh Exp*Prelection*DSP & & $\begin{array}{l}0.73^{* * *} \\
(7.01)\end{array}$ \\
\hline Neigh Exp*Prelection* No DSP & & $\begin{array}{l}0.68^{* * *} \\
(7.29)\end{array}$ \\
\hline Neigh Exp*No Prelection & & $\begin{array}{l}0.63^{* * *} \\
(6.8)\end{array}$ \\
\hline Election*DSP & $\begin{array}{l}0.55 \\
(0.64)\end{array}$ & \\
\hline Election* No DSP & $\begin{array}{l}0.02 \\
(0.02)\end{array}$ & \\
\hline Election & & $\begin{array}{c}-0.004 \\
(-0.66)\end{array}$ \\
\hline No Election & $\begin{array}{l}0.17 \\
(0.20)\end{array}$ & \\
\hline Prelection*DSP & & $\begin{array}{l}-0.21 \\
(-0.22)\end{array}$ \\
\hline Prelection*No DSP & & $\begin{array}{l}0.19 \\
(0.22)\end{array}$ \\
\hline Prelection & $\begin{array}{c}-0.005 \\
(-0.78)\end{array}$ & \\
\hline No Prelection & & $\begin{array}{l}0.46 \\
(0.5)\end{array}$ \\
\hline Density & $\begin{array}{c}-1.30^{* * *} \\
(-10.61)\end{array}$ & $\begin{array}{c}-1.36^{* * *} \\
(-10.85)\end{array}$ \\
\hline Population & $\begin{array}{l}0.84^{* * *} \\
(12.90)\end{array}$ & $\begin{array}{l}0.86^{* * *} \\
(13.62)\end{array}$ \\
\hline Young & $\begin{array}{l}0.088^{* *} \\
(2.82)\end{array}$ & $\begin{array}{l}0.10^{* * *} \\
(3.24)\end{array}$ \\
\hline Old & $\begin{array}{l}0.05 \\
(0.88)\end{array}$ & $\begin{array}{l}0.078 \\
(1.44)\end{array}$ \\
\hline Income per-head & $\begin{array}{l}-0.02 \\
(-0.53)\end{array}$ & $\begin{array}{l}-0.01 \\
(-0.43)\end{array}$ \\
\hline Grants per-head & $\begin{array}{l}0.05^{* * *} \\
(3.88)\end{array}$ & $\begin{array}{l}0.05^{* * *} \\
(3.45)\end{array}$ \\
\hline Majority & $\begin{array}{l}0.003 \\
(0.20)\end{array}$ & $\begin{array}{c}-0.001 \\
(-0.12)\end{array}$ \\
\hline Left-wing coal. & $\begin{array}{l}0.03^{* * *} \\
(4.19)\end{array}$ & $\begin{array}{l}0.02^{* * *} \\
(3.83)\end{array}$ \\
\hline Right-wing coal. & $\begin{array}{l}0.02^{* *} \\
(2.69)\end{array}$ & $\begin{array}{l}0.02^{* *} \\
(2.49)\end{array}$ \\
\hline Centred $\mathrm{R}^{2}$ & 0.975 & \\
\hline Hansen $\mathrm{J}$ test & 0.211 & 0.107 \\
\hline$\rho$ test $=0$ & 0.210 & $0.093^{*}$ \\
\hline$\varphi$ test $=0$ & 0.179 & $0.088^{*}$ \\
\hline
\end{tabular}

Note: $i$ ) instrument variables in model 5 are the regressors, the regressors average interacted with the electoral (pre-electoral) dummies and the DSP dummy, the election index, the pre-election index, and the average of the election index; ii) results of the tests are in p-value; iii) coefficient significant at level $* * * 1 \%, * * 5 \%, * 10 \% ; i v$ ) z-value in parenthesis; $v$ ) observations: 2460 . 


\section{References}

Alesina, A. and T. Bayoumi (1996). The costs and benefits of fiscal rules: evidence from U.S. states. NBER Working Paper 5614.

Alesina, A., G. Cohen, and N. Roubini (1992). Macroeconomic policy and elections in OECD democracies. Economics and Politics 4, 1-30.

Allers, M. and J. P. Elhorst (2005). Tax mimicking and yardstick competition among local governments in the Netherlands. International Tax and Public Finance 12, 493-513.

Anderson, T. W. and C. Hsiao (1981). Estimation of dynamic models with error components. Journal of the American Statistical Association 76 (375), 598-606.

Anderson, T. W. and C. Hsiao (1982). Formulation and estimation of dynamic models using panel data. Journal of Econometrics 18(1), 47-82.

Anselin, L. (1988). Spatial Econometrics: Methods and Models. Kluwer.

Anselin, L., J. Le Gallo, and J. H (2008). Spatial panel econometrics. In L. Mátyás and P. Sevestre (Eds.), The Econometrics of Panel Data, Fundamentals and Recent Developments in Theory and Practice (3rd Edition ed.)., pp. 625-660. Berlin Heidelberg: Springer - Verlag.

Arellano, M. and S. Bond (1991). Some tests of specification for panel data: Monte carlo evidence and an application to employment equations. The Review of Economic Studies 58(2), 277-297.

Arellano, M. and O. Bover (1995). Another look at the instrumental variable estimation of error-components models. Journal of Econometrics 68(1), $29-51$.

Baum, C. F., M. E. Schaffer, and S. Stillman (2003). Instrumental variables and GMM: Estimation and testing. Working Paper 545, Boston College.

Besley, T. and A. Case (1995a). Does electoral accountability affect economic policy choices? Evidence from gubernatorial term limits. Quarterly Journal of Economics 110, 769-798.

Besley, T. and A. Case (1995b). Incumbent behavior: Vote-seeking, tax setting, and yardstick competition. American Economic Review 85, 25-45.

Bhattacharyya, D. K. and R. W. Wassmer (1995). Fiscal dynamics of local elected officials. Public Choice 83, 221-249.

Blundell, R. and S. Bond (1998). Initial conditions and moment restrictions in dynamic panel data models. Journal of Econometrics 87(1), 115-143. 
Blundell, R. and S. Bond (2000). Gmm estimation with persistent panel data: an application to production functions. Econometric Reviews 19(3), 321340 .

Bond, S. R., A. Hoeffler, and J. Temple (2001). Gmm estimation of empirical growth models. CEPR Discussion Papers 3048, C.E.P.R. Discussion Papers.

Bordignon, M., F. Cerniglia, and F. Revelli (2003). In search of yardstick competition: a spatial analysis of Italian municipality property tax setting. Journal of Urban Economics 54(2), 199-217.

Bowsher, C. G. (2002). On testing overidentifying restrictions in dynamic panel data models. Economics Letters 77(2), 211-220.

Ermini, B. and R. Santolini (2007). Horizontal interaction on local councils' expenditures. evidence from Italy. Working Paper no. 278, Department of Economics, Università Politecnica delle Marche.

Franzese, R. J. (2000). Electoral and partisan manipulation of public debt in developed democracies, 1956-1990. In R. Strauch and J. Von Hagen (Eds.), Institutions, Politics and Fiscal Policy, pp. 61-83. Kluwer Academic Press.

Galli, E. and S. Rossi (2002). Political budget cycles: the case of the western German lander. Public Choice 110, 283-303.

Kelejian, H. H. and I. R. Prucha (1998). A generalized spatial two stage least squares procedure for estimating a spatial autoregressive model with autoregressive disturbances. SSRN eLibrary.

Mink, M. and J. De Haan (2005). Has the stability and growth pact impeded political budget cycles in the European Union? CESifo Working Paper 1535.

Mouritzen, P. E. (1989). The local political business cycle. Scandinavian Political Studies 12(1), 37-55.

Nordhaus, W. D. (1975). The political business cycle. Review of Economic Studies 42(2), 169-190.

Patrizii, V., C. Rapallini, and G. Zito (2005). I patti di stabilita interni. Dipartimento di Studi dello Stato, Universita degli Studi di Firenze.

Petterson-Lidbom, P. (2003). A test of rational electoral-cycle hypothesis. Working Paper, University of Stockholm.

Poterba, J. M. (1995). Balanced budget rules and fiscal policies: evidence from the state. National Tax Journal 48(3), 329-336.

Rogoff, K. (1990). Equilibrium political budget cycles. American Economic Review 80, 21-36. 
Roodman, D. (2007). A note on the theme of too many instruments. Working Papers 125, Center for Global Development.

Salmon, P. (1987). Decentralisation as an incentive scheme. Oxford Review of Economic Policy 3(2), 24-43.

Santolini, R. (2008). A spatial cross-sectional analysis of political trend in the Italian municipalities. Papers in Regional Science 87, 431-451.

Shi, M. and J. Svensson (2002). Political budget cycles in developed and developing countries. Mimeo.

Solé-Ollé, A. (2003). Electoral accountability and tax mimicking: the effects of electoral margins, coalition government, and ideology. European Journal of Political Economy 19, 685-713.

Solé-Ollé, A. (2006). Expenditure spillovers and fiscal interactions: Empirical evidence from local governments in spain. Journal of Urban Economics 59(1), 32-53.

Sutherland, D., R. Price, and I. Joumard (2005). Fiscal rules for sub-central governments. OECD Economics Department Working Papers No. 465.

Veiga, L. G. and F. J. Veiga (2007). Political business cycles at the municipal level. Public Choice 131, 45-64.

Verbeek, M. (2008). A guide to modern econometrics (3rd edition ed.). John Wiley \& Sons.

Von Hagen, J. (1991). A note on the empirical effectiveness of formal fiscal restrains. Journal of Public Economics 44, 199-210. 


\section{CESifo Working Paper Series}

for full list see www.cesifo-group.org/wp

(address: Poschingerstr. 5, 81679 Munich, Germany, office@cesifo.de)

2541 Philipp C. Bauer and Regina T. Riphahn, Age at School Entry and Intergenerational Educational Mobility, February 2009

2542 Thomas Eichner and Rüdiger Pethig, Carbon Leakage, the Green Paradox and Perfect Future Markets, February 2009

2543 M. Hashem Pesaran, Andreas Pick and Allan Timmermann, Variable Selection and Inference for Multi-period Forecasting Problems, February 2009

2544 Mathias Hoffmann and Iryna Shcherbakova, Consumption Risk Sharing over the Business Cycle: the Role of Small Firms' Access to Credit Markets, February 2009

2545 John Beirne, Guglielmo Maria Caporale, Marianne Schulze-Ghattas and Nicola Spagnolo, Volatility Spillovers and Contagion from Mature to Emerging Stock Markets, February 2009

2546 Ali Bayar and Bram Smeets, Economic and Political Determinants of Budget Deficits in the European Union: A Dynamic Random Coefficient Approach, February 2009

2547 Jan K. Brueckner and Anming Zhang, Airline Emission Charges: Effects on Airfares, Service Quality, and Aircraft Design, February 2009

2548 Dolores Messer and Stefan C. Wolter, Money Matters - Evidence from a Large-Scale Randomized Field Experiment with Vouchers for Adult Training, February 2009

2549 Johannes Rincke and Christian Traxler, Deterrence through Word of Mouth, February 2009

2550 Gabriella Legrenzi, Asymmetric and Non-Linear Adjustments in Local Fiscal Policy, February 2009

2551 Bruno S. Frey, David A. Savage and Benno Torgler, Surviving the Titanic Disaster: Economic, Natural and Social Determinants, February 2009

2552 Per Engström, Patrik Hesselius and Bertil Holmlund, Vacancy Referrals, Job Search, and the Duration of Unemployment: A Randomized Experiment, February 2009

2553 Giorgio Bellettini, Carlotta Berti Ceroni and Giovanni Prarolo, Political Persistence, Connections and Economic Growth, February 2009

2554 Steinar Holden and Fredrik Wulfsberg, Wage Rigidity, Institutions, and Inflation, February 2009

2555 Alexander Haupt and Tim Krieger, The Role of Mobility in Tax and Subsidy Competition, February 2009 
2556 Harald Badinger and Peter Egger, Estimation of Higher-Order Spatial Autoregressive Panel Data Error Component Models, February 2009

2557 Christian Keuschnigg, Corporate Taxation and the Welfare State, February 2009

2558 Marcel Gérard, Hubert Jayet and Sonia Paty, Tax Interactions among Belgian Municipalities: Does Language Matter?, February 2009

2559 António Afonso and Christophe Rault, Budgetary and External Imbalances Relationship: A Panel Data Diagnostic, February 2009

2560 Stefan Krasa and Mattias Polborn, Political Competition between Differentiated Candidates, February 2009

2561 Carsten Hefeker, Taxation, Corruption and the Exchange Rate Regime, February 2009

2562 Jiahua Che and Gerald Willmann, The Economics of a Multilateral Investment Agreement, February 2009

2563 Scott Alan Carson, Demographic, Residential, and Socioeconomic Effects on the Distribution of $19^{\text {th }}$ Century US White Statures, February 2009

2564 Philipp Harms, Oliver Lorz and Dieter Urban, Offshoring along the Production Chain, February 2009

2565 Patricia Apps, Ngo Van Long and Ray Rees, Optimal Piecewise Linear Income Taxation, February 2009

2566 John Whalley and Shunming Zhang, On the Arbitrariness of Consumption, February 2009

2567 Marie-Louise Leroux, Endogenous Differential Mortality, Non-Contractible Effort and Non Linear Taxation, March 2009

2568 Joanna Bęza-Bojanowska and Ronald MacDonald, The Behavioural Zloty/Euro Equilibrium Exchange Rate, March 2009

2569 Bart Cockx and Matteo Picchio, Are Short-Lived Jobs Stepping Stones to Long-Lasting Jobs?, March 2009

2570 David Card, Jochen Kluve and Andrea Weber, Active Labor Market Policy Evaluations: A Meta-analysis, March 2009

2571 Frederick van der Ploeg and Anthony J. Venables, Harnessing Windfall Revenues: Optimal Policies for Resource-Rich Developing Economies, March 2009

2572 Ondřej Schneider, Reforming Pensions in Europe: Economic Fundamentals and Political Factors, March 2009 
2573 Jo Thori Lind, Karl Ove Moene and Fredrik Willumsen, Opium for the Masses? Conflict-Induced Narcotics Production in Afghanistan, March 2009

2574 Silvia Marchesi, Laura Sabani and Axel Dreher, Agency and Communication in IMF Conditional Lending: Theory and Empirical Evidence, March 2009

2575 Carlo Altavilla and Matteo Ciccarelli, The Effects of Monetary Policy on Unemployment Dynamics under Model Uncertainty - Evidence from the US and the Euro Area, March 2009

2576 Falko Fecht, Kjell G. Nyborg and Jörg Rocholl, The Price of Liquidity: Bank Characteristics and Market Conditions, March 2009

2577 Giorgio Bellettini and Filippo Taddei, Real Estate Prices and the Importance of Bequest Taxation, March 2009

2578 Annette Bergemann and Regina T. Riphahn, Female Labor Supply and Parental Leave Benefits - The Causal Effect of Paying Higher Transfers for a Shorter Period of Time, March 2009

2579 Thomas Eichner and Rüdiger Pethig, EU-Type Carbon Emissions Trade and the Distributional Impact of Overlapping Emissions Taxes, March 2009

2580 Antonios Antypas, Guglielmo Maria Caporale, Nikolaos Kourogenis and Nikitas Pittis, Selectivity, Market Timing and the Morningstar Star-Rating System, March 2009

2581 António Afonso and Christophe Rault, Bootstrap Panel Granger-Causality between Government Budget and External Deficits for the EU, March 2009

2582 Bernd Süssmuth, Malte Heyne and Wolfgang Maennig, Induced Civic Pride and Integration, March 2009

2583 Martin Peitz and Markus Reisinger, Indirect Taxation in Vertical Oligopoly, March 2009

2584 Petra M. Geraats, Trends in Monetary Policy Transparency, March 2009

2585 Johannes Abeler, Armin Falk, Lorenz Götte and David Huffman, Reference Points and Effort Provision, March 2009

2586 Wolfram F. Richter, Taxing Education in Ramsey’s Tradition, March 2009

2587 Yin-Wong Cheung, Menzie D. Chinn and Eiji Fujii, China's Current Account and Exchange Rate, March 2009

2588 Alexander Haupt and Silke Uebelmesser, Voting on Labour-Market Integration and Education Policy when Citizens Differ in Mobility and Ability, March 2009

2589 Hans Jarle Kind, Marko Koethenbuerger and Guttorm Schjelderup, Should UtilityReducing Media Advertising be Taxed?, March 2009 
2590 Alessandro Cigno, How to Avoid a Pension Crisis: A Question of Intelligent System Design, March 2009

2591 Helmut Lütkepohl and Fang $\mathrm{Xu}$, The Role of the Log Transformation in Forecasting Economic Variables, March 2009

2592 Rainald Borck, Hyun-Ju Koh and Michael Pflüger, Inefficient Lock-in and Subsidy Competition, March 2009

2593 Paolo M. Panteghini, On the Equivalence between Labor and Consumption Taxation, March 2009

2594 Bruno S. Frey, Economists in the PITS?, March 2009

2595 Natalie Chen and Dennis Novy, International Trade Integration: A Disaggregated Approach, March 2009

2596 Frédérique Bec and Christian Gollier, Term Structure and Cyclicity of Value-at-Risk: Consequences for the Solvency Capital Requirement, March 2009

2597 Carsten Eckel, International Trade and Retailing, March 2009

2598 Gianni De Nicolò and Iryna Ivaschenko, Global Liquidity, Risk Premiums and Growth Opportunities, March 2009

2599 Jay Pil Choi and Heiko Gerlach, International Antitrust Enforcement and Multi-Market Contact, March 2009

2600 Massimo Bordignon and Guido Tabellini, Moderating Political Extremism: Single Round vs Runoff Elections under Plurality Rule, April 2009

2601 Ana B. Ania and Andreas Wagener, The Open Method of Coordination (OMC) as an Evolutionary Learning Process, April 2009

2602 Simon Gächter, Daniele Nosenzo, Elke Renner and Martin Sefton, Sequential versus Simultaneous Contributions to Public Goods: Experimental Evidence, April 2009

2603 Philippe Jehiel and Andrew Lilico, Smoking Today and Stopping Tomorrow: A Limited Foresight Perspective, April 2009

2604 Andreas Knabe, Steffen Rätzel, Ronnie Schöb and Joachim Weimann, Dissatisfied with Life, but Having a Good Day: Time-Use and Well-Being of the Unemployed, April 2009

2605 David Bartolini and Raffaella Santolini, Fiscal Rules and the Opportunistic Behaviour of the Incumbent Politician: Evidence from Italian Municipalities, April 2009 